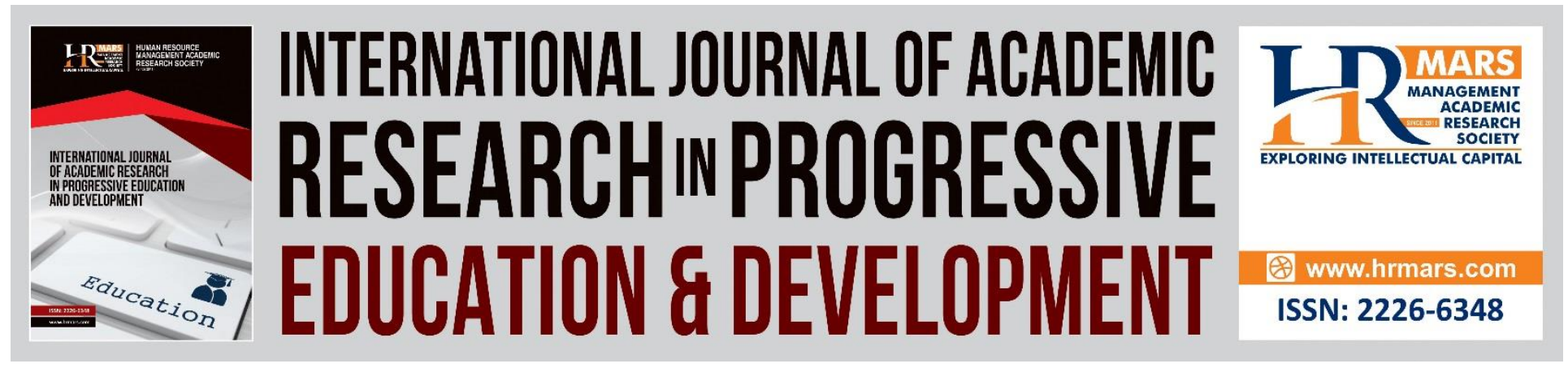

\title{
Workers Job Security and Productivity in Missionary Educational Centres in Delta State, Nigeria
}

Nkedishu, Victor Chukwubueze

To Link this Article: http://dx.doi.org/10.6007/IJARPED/v9-i4/8459

DOI:10.6007/IJARPED/v9-i4/8459

Received: 11 November 2020, Revised: 07 December 2020, Accepted: 18 December 2020

Published Online: 31 December 2020

In-Text Citation: (Nkedishu, 2020)

To Cite this Article: Nkedishu, V. C. (2020). Workers Job Security and Productivity in Missionary Educational Centres in Delta State, Nigeria. International Journal of Academic Research in Progressive Education and Development, 9(4), 192-203.

Copyright: (C) 2020 The Author(s)

Published by Human Resource Management Academic Research Society (www.hrmars.com)

This article is published under the Creative Commons Attribution (CC BY 4.0) license. Anyone may reproduce, distribute, translate and create derivative works of this article (for both commercial and non-commercial purposes), subject to full attribution to the original publication and authors. The full terms of this license may be seen at: http://creativecommons.org/licences/by/4.0/legalcode

Vol. 9(4) 2020, Pg. 192 - 203

http://hrmars.com/index.php/pages/detail/IJARPED

JOURNAL HOMEPAGE

Full Terms \& Conditions of access and use can be found at http://hrmars.com/index.php/pages/detail/publication-ethics 


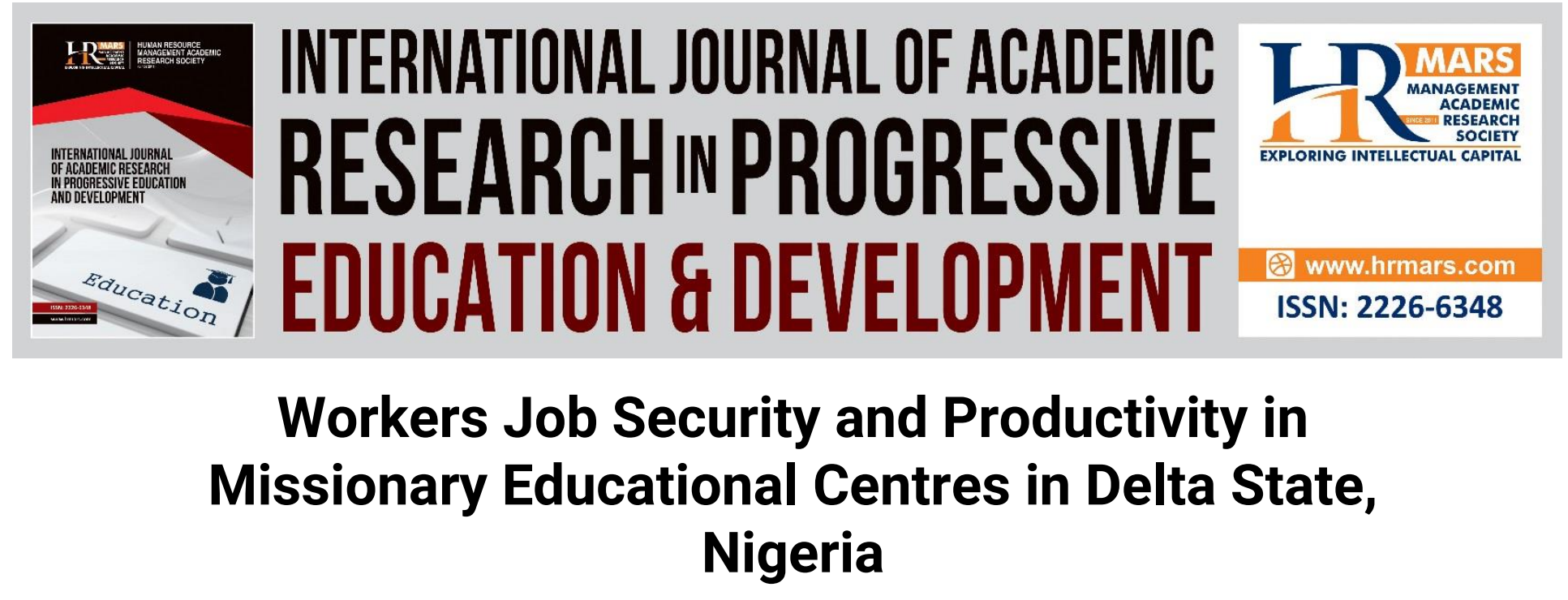

\author{
Nkedishu, Victor Chukwubueze \\ Department of Educational Management and Foundations, Delta State University, Abraka, \\ Nigeria. \\ Email: chuksjp@gmail.com
}

\begin{abstract}
This study empirically examined workers job security and productivity in missionary education centres in Delta State, Nigeria. This study adopted an ex-post-facto research design of the descriptive survey method. A sample of 436 school personnel (114 principals plus 322 teachers) was drawn from a population 1188 school teachers including principals using stratified sampling technique. Self-structured questionnaire, titled "Workers Job Security and Productivity Questionnaire, (WJSPQ)" was used to seek information. Data analysis was done using descriptive statistics and t-test statistics at 0.05 level of significance. Findings revealed that ways to provide job security for workers includes; constant training of workers, provide adequate physical and instructional facilities, allow workers to be passive when making decision and seek workers' view on how to enhance the school. Also, job security could influence workers' productivity by making workers productive on their task, give workers sense of belonging, make workers abide to school rules, reduce workers interest to leave the job and fulfil psychological need of the workers. It was recommended that workers should be allowed to participate in decision making, through this, workers will feel the impact of the school organisation as feel less insured in the school.
\end{abstract}

Keywords: Workers Job Security, Productivity, Missionary Education Centers, Delta State.

\title{
Introduction
}

Right from the time the British berthed at the shores of Nigeria, they made efforts to get Nigerians to learn about their foreign ways. The customary kinds of teaching were already in invoke prior to the arrival of western colonial masters, but many parents insisted on their children learning both the traditional and western form of education. This was the reason western education was not recognized in Nigerian society until the 20th century, when the British interests were firmly rooted in Nigeria. The British interest were on British commerce, formal colonial masters, and the Christian Missionary. The Christian missionary began to educate young children particularly boys through establishment of missionary, on British ways of living, although 
most parents refused to release their female child/children to attend school. In 1843 the Methodist Church built the first school and taught western education in Nigeria (Marr, 2015).

The school was founded in Badagry and named St Thomas' Anglican Nursery and Primary School, established by Rev. Golmer. At present the school is over 176 years old. Later, other school sprang up in Nigeria such as CMS Grammar School of 1859, Methodist Boys High School, Methodist Girls High School, Baptists Academy of 1885, Kings College of 1909, established in Lagos respectively. Also, Abeokuta Grammar School of 1908, ljebu-Ode Grammar School of 1913, Eko Boys High School and Ondo boys High School sprang up later. Not forgetting Dennis Memorial Grammar School, Anambra, of 1925. Hope Waddell Training Institute, Calabar, established in 1895 was the first higher institution to be founded.

Missionary schools are spreading like a wide fire in virtually every state of the federation today, with the inclusion of Delta State. This is due partly to the value that people have come to attach to education in Nigeria on the one hand and the quality of education offered by the missionaries on the other. As described by Ogunu (2014), missionary schools were characterised by; effective supervision of programmes and individual workers in the schools, provision of infrastructure for effective learning and teaching, recruitment of qualified teachers who saw the work as a vocation, credible admission policies, unwavering commitment demonstrated with high level of performance and remarkable involvement of stakeholders in the processes of instilling discipline and control. The above conditions paved the way for students to develop some of the following attributes; willingness to learn to excel and develop credible reasoning and common sense, desire to share with others and values of brotherliness, curiosity to search for opportunities, willingness to obey rules and regulations and honesty in all spheres of life at all times and in all places with minimum supervision.

However, many of these qualities of education and discipline that students received from the missionary schools in the past are fast eroding today due to the climates that are prevalent in many of these schools. Some missionary schools today, do not seem to be giving the right environment to their teachers for them to work and bring out the best in them. It is a known fact from research, that education is very critical to the national development of any country, and in every educational system, teachers constitute a very vital component. Despite the remarkable advancement in technology in all areas of teaching and learning, from the usage of sophisticated instructional materials such as magnetic white boards; computer projectors of several kinds, etc., down to the basic instructions that are given in the classrooms daily, the teacher is still crucially significant feature for motivating and conveying knowledge to learners at different educational level. The magnitude to which teachers attain this vital role of conveying knowledge is liable on their productivity.

Workers productivity entails all activities discharged by the teacher in order to accomplish the desired effects on the students. It involves the degree to which teachers participates in the overall running of the school in order to achieve the expected objectives and goals of the school. In other words, performance is the accomplishment of school goals. Teacher's productivity is very crucial to students' academic progress and development. The progress of a student will have a direct link with the successful teaching - learning process in the classroom. Teacher's productivity is related to what the teachers do in the classroom and how that affects the student's learning. As the principal of a school, what teachers perform in the classroom must be given serious 
attention since this can greatly influence the whole process of students' learning and, in turn, affect the quality of school leavers (Werang, 2014). Thus, teachers play very pivotal roles in ensuring students' academic achievements in the school system and the productivity of teachers to a great extent depends on the climate of each particular school.

Security is a great persuader that permits an individual to move on in life, it leads to sense of fulfilment and satisfaction when an individual understands that they are secured/safe in whatever profession they involved themselves. When a person is safe/secured then they can seek to achieve other things so desired (Abolade, 2013). Once an individual is assured of security especially of his job, and he sees it practically displayed, he may be motivated to be the best he could be since nothing poses as a threat to him in this wise. The workplace is expected to be a comfort zone for workers and a place of refuge from some challenges of life like economic and social challenges which are some of the aftermath of losing one's job. The most imperative thing an employee needs in employment relationship is job security that guarantees peace of mind. Security is one of the second fundamental needs of man as postulated by Maslow's hierarchy of needs. Langbert (2012) declared that security needs are indispensable needs, for desire, physical safety and to be free from fear of deprivation and physiological needs.

Job security to an employee is that his/her job is not threatened and that the individual will be on the job for as long as the individual wants with no feeling or reasons whether objective or subjective that he/she might lose the job. With the present situation where there are so many layoffs, early retirement, contract staff and part-time employees, workers may not be certain that they will be in their employment for longer period as many employers of labour now lay off their employees due to economic reasons and the inability of some workers to keep pace with the dynamic changes experienced in the universe. This situation could lead to challenge/threat to the workers in diverse employments who are not convinced of what might be their survival in this era of sacks and even premature retirement, could also affect performance of the organisation. It is generally believed that once an employee on the job passes the probationary period, the need for job security quickly appears to recede its importance (Abolade, 2018). As this is achieved, the individual becomes relaxed and complacent in a job situation. Although reverse is the case with Delta State missionary education centres as most schools hardly guarantee job security. This situation has resulted to most teachers leaving the schools to seek for a better job with security.

\section{Statement of the Problem}

Mobility of job have been observed to be swift in the missionary education centres than the public secondary schools particularly in Delta State as a result of job insecurity. More significantly, frequent resignations of duties in the missionary education centres either with or without notice tend to have much bearings on lack of clearly defined conditions of service, poor working environment and job insecurity. School administrators in missionary education centres in Delta State tend to be more interested in increased performance through excess work load at a minimal cost. However, most school administrators of missionary education centres claimed that it is through their effort towards adequate provision of good work environment and workers' incentives that tend to promote staff/management relationship and students' high academic achievement. Arising from the above flaws that the researcher is challenged to examine if there 
is any influence of job security on workers' productivity in missionary education centres in Delta State.

\section{Purpose of the Study}

This study empirically examined workers job security and productivity in missionary education centres in Delta State, Nigeria. With specific intention of ascertaining ways could missionary education centres provide job security for workers, areas are workers productive on their job and influence of job security on workers' productivity in missionary education centres.

\section{Research Questions}

1. In what ways could missionary education centres provide job security for workers?

2. In what areas are workers productive on their job?

3. What is the influence of job security on workers' productivity in missionary education centres in Delta State?

\section{Hypotheses}

1. Sex opinion does not significantly differ on ways missionary education centres provide job security for workers?

2. Administrators experience does not significantly differ on rating of workers productive.

3. Employers and employees mean rating does not significantly differ on how workers job security influence productivity in Delta State missionary education centres.

\section{Literature Review}

\section{Job Security as a Concept}

Job insecurity might be considered as job stressors, and such is predictive of changes over time in both job satisfaction and physical symptoms. According to results of the research, protracted periods of job insecurity decline job satisfaction and upsurge physical symptomatology, over or above effects of job insecurity at any point in time. Moreover, decreased performance, and an inclination to leave the job are assumed to be a consequence of job insecurity (Heydy \& Didona, 2017). Thus, like any other stressor, job insecurity is linked to reduce wellbeing, and negative emotions toward the instrument perceived as the cause of the stress. The perception of job insecurity could therefore be associated with performance decrease and an overall reduction in organizational citizenship behaviours. Dissatisfied and less committed teachers are less like to be dedicated to achieve the goals and objectives of education. Another study, a meta-analysis and review of job insecurity and its consequences, performed by Sverke, Hellgren, and Naswall (2002), reviewed that the behavioural consequences of insecurity are detrimental for employee's job attitude, organizational attitudes and health. The analysis suggested that the relationship between job security and employee's performance and behaviour may be underestimated on studies that rely on single-item measures wherein respondents are asked to rate the perceived probability of losing their jobs, or express their satisfaction with the perceived job security.

Causes of job insecurity could attributed to lack of training, technology, inability of workers' inability to keep with the new trends, and management attitude to employee welfare 
and economic challenges. Other include; low level of education, inadequate required skills, poor attitude to duties, grievances, insubordination, work under-load, lack of discipline, workoverload and working against ethics of the organisation. Blue-collar workers; low skilled individuals; employees in the industrial sector and those with temporary job contract perceive themselves were ascertained as being job-unsecured by De Witte (2005).

\section{Teacher Productivity as a Concept}

A teacher is a person trained in knowledge, skills, attitude and values, in a formal training institution, to teach or impart same to the learners in the most acceptable way. Teachers could be described as the human catalyst who intentionally influences the interaction among the teacher, the learner and the environment of the learner by restructuring the environment of the learner in such a way that the learner will acquire the desired knowledge, skills and attitudes and meaningfully contribute to the development of humanity at an appropriate time. Hence, the success or failure of any education system depends to a large extent on the quality and calibre of teachers who is referred to as interpreters and transmitters of required knowledge, attitudes, skills, and values in society. Productivity of teachers could be portrayed as the tasks executed by the teacher at a specific time in the instructive structure in accomplishing administrative objectives (Olaniyan, 2009). Productivity is somewhat, what a singular individual does. Execution of the tutors in educational institutions is exceptionally impacted by motivation.

Job productivity of employees remains an issue of incredible concern to numerous organizations such as school. Job productivity is concerned with the general adequacy and effectiveness of completing things. It gives an indication of how an organization is fairing. The idea of job productivity can be seen from numerous points of view like financial, industry and administration. According to Nwachukwu (2016), job productivity is the output, resulting from a given resources input at a given time. Mali (2015) described job productivity as achieving the top of productivity with minimal use of assets. Thus, job productivity is a fundamental element in financial improvement as it legitimizes vast use by the association and has several other helpful influences. Conclusively job productivity involves accomplishing more with less assets, making more from what you have preferably more smart than harder, it is basic to look at the different method for empowering job productivity in our prompt society.

\section{Job Security and Workers Productivity}

Job insecurity is one of the socio-psychological problems which are predominant in the developing countries such as Nigeria. It is characterised by poor wages, loss of pay, issue of downsizing, lack of accommodation, lack of consideration for promotion, possibility of dismissal and application of dragonian rules. Job insecurity tends to result in a sense of worthlessness and miserable future for a worker or teacher in such a system. Lack of job security could be accountable for turnover rate of teacher. Research findings abound which indicate that when teachers are dissatisfied with their tasks due to lack of job security they respond to circumstances by seeking other jobs and leaving teaching profession. In Florida, Blazer (2006) study specified that $20 \%$ of fresh teachers in Miami-Dade County school, United States of America experienced teachers' turnover after three years and nearly $30 \%$ left after five years due to perceived job insecurity. 
In Canada, Coulter and Abney (2009) established that teachers are leaving their profession and at an alarming rate than any other profession. A huge number of teachers depart the teaching profession due to lack of adequate salaries, inadequate job security, houses and promotion opportunities (Kamara 2002). In Zimbabwe about 2000 newly qualified teachers lost their job for greener pastures in year 2000 due to perceived inadequate of job security (Mukumbira 2001). Chaika (2002) advocated that lack of teachers' mobility, inadequate induction programme, lack of job security and poor working conditions were bases for teacher turnover. Kampala, Uganda, Wakiso District Candle (2010) revealed employers related factors such as teachers' low salary, lack of job security and poor working conditions as having positive significant effect on teachers' turnover. Subramaniam, et al (2011) established that job security is not significantly related to organisational performance. Senem and Ozgur (2017) discovered a high employees' burnout level in emotional fatigue and individual achievement at low level in depersonalization. Also, results of relationship among performance, burnout, and creativity were substantial. Thus, burnout is another source influencing job performance. Abolade (2018) establish that job insecurity adversely affect performance in organisation and persuade employee turnover. Aloysius and Ngozika (2019) revealed positive substantial relationship between teachers' job security and retention.

\section{Methods}

This study adopted an ex-post-facto research design of the descriptive survey method in examining the variables. The population was 1188 school teachers including principals, (114 principals and 1073 teachers) in 40 missionary schools in Delta State. Out of which a sample of 436 school personnel (114 principals plus 322 teachers) were used for the study. Representing $114(100 \%)$ and $322(30 \%)$ of the participants studied. Stratified sampling technique was adopted in sampling participants for the study. All the selected principals, vice-principals and teachers were merged to form the sample for the study. The research instrument that was utilized for data collection in this study was a self-structured questionnaire, titled "Workers Job Security and Productivity Questionnaire, (WJSPQ)" to solicit information from the respondents. To ensure face and content validities of the instruments, the initial draft was given to two experts who were requested to examine the items on the instruments to find out if they were adequate and suitable for the study. Their comments, criticisms, suggestions and recommendations were included in the final draft of the instrument. To ensure that the instrument measured considerably and consistently what it intended to measure, it was subjected to a split-half reliability test using 20 respondents who were excluded from the main study and a co-efficient of 0.86 was obtained which showed a high reliability index. For the purpose of data analysis, descriptive statistics was used to answer the research question while in testing the hypotheses, t-test statistics was employed at 0.05 level of significance.

\section{Presentation of Results}

Research Question 1: In what ways could missionary education centres provide job security for workers? 
Vol. 9, No. 4, 2020, E-ISSN: $2226-6348$ @ 2020 HRMARS

Table 1: Mean rating and SD analysis on ways to provide job security for workers

\begin{tabular}{|r|l|c|c|l|}
\hline \multicolumn{1}{|l}{ S/N } & Ways to provide job security for workers & Mean & SD & Verdict \\
\hline 1. & lonstant training of workers & 3.26 & .80 & Agree \\
\hline 2. & Provide adequate physical facilities & 2.86 & .78 & Agree \\
\hline 3. & Provide adequate instructional facilities & 3.18 & .80 & Agree \\
\hline 4. & $\begin{array}{l}\text { Encourage workers to attend professional development } \\
\text { programmes }\end{array}$ & 3.08 & .80 & Agree \\
\hline 5. & Allow workers to be passive when making decision & 3.00 & .78 & Agree \\
\hline 6. & $\begin{array}{l}\text { Make workers feel the impact of management through } \\
\text { democratic leadership }\end{array}$ & 3.02 & .79 & Agree \\
\hline 7. & Seek workers opinion of how to improve the school & 3.28 & .83 & Agree \\
\hline
\end{tabular}

Result in Table 1 shows mean rating and SD analysis on ways to provide job security for workers. With benchmark of 2.50, the respondents have agreed on all the items. Thus, ways to provide job security for workers includes; constant training of workers, provide adequate physical and instructional facilities, encourage workers to attend professional development programmes, allow workers to be passive when making decision, make workers feel the impact of management through democratic leadership and seek workers' view on how to enhance the school.

Research Question 2: In what areas are workers productive on their job?

Table 2: Mean rating and SD analysis on areas workers are productive

\begin{tabular}{|r|l|c|c|l|}
\hline S/N & Areas workers are productive & Mean & SD & Verdict \\
\hline 1. & Task assigned to workers were delivered & 3.22 & .76 & Agree \\
\hline 2. & Teaching students & 3.08 & .82 & Agree \\
\hline 3. & Preparing lesson note & 3.10 & .86 & Agree \\
\hline 4. & Making students scripts & 3.06 & .79 & Agree \\
\hline 5. & Preparing students results & 2.94 & .76 & Agree \\
\hline 6. & Ensure that discipline is maintained within the school & 2.84 & .84 & Agree \\
\hline 7. & Regular to school & 2.92 & .85 & Agree \\
\hline
\end{tabular}

Result in Table 2 shows mean rating and SD analysis on areas workers are productive. With benchmark of 2.50, the respondents have agreed on all the items. Thus, areas workers are productive includes; task assigned to workers were delivered, teaching students, preparing lesson note, making students scripts, preparing students results, ensure that discipline is maintained within the school and regular to school.

Research Question 3: What is the influence of job security on workers' productivity in missionary education centres in Delta State? 
Vol. 9, No. 4, 2020, E-ISSN: $2226-6348$ @ 2020 HRMARS

Table 3: Mean rating and SD analysis on influence of job security on workers' productivity

\begin{tabular}{|r|l|c|l|l|}
\hline S/N & Influence of job security on workers' productivity & Mean & SD & Verdict \\
\hline 1. & Make workers productive on their task & 3.12 & .85 & Agree \\
\hline 2. & Give workers sense of belonging & 2.79 & .76 & Agree \\
\hline 3. & Help workers to be dedicated to their job & 2.89 & .80 & Agree \\
\hline 4. & Make workers abide to school rules & 2.95 & .79 & Agree \\
\hline 5. & Make workers acquire more skills on the job & 3.04 & .82 & Agree \\
\hline 6. & Reduce workers interest to leave the job & 3.20 & .79 & Agree \\
\hline 7. & Fulfil psychological need of the workers & 2.94 & .81 & Agree \\
\hline
\end{tabular}

Result in Table 3 shows mean rating and SD analysis on influence of job security on workers' productivity. With benchmark of 2.50 , the respondents have agreed on all the items. Thus, influence of job security on workers' productivity includes; make workers productive on their task, give workers sense of belonging, help workers to be dedicated to their job, make workers abide to school rules, acquire more skills on the job, reduce workers interest to leave the job and fulfil psychological need of the workers.

Hypothesis 1: Sex opinion does not significantly differ on ways missionary education centres provide job security for workers?

Table 4: t-test summary of sex opinion on ways to provider job security for workers

\begin{tabular}{|l|l|l|l|l|l|l|l|}
\hline \multicolumn{1}{|c|}{ Sex } & \multicolumn{1}{c|}{$\mathbf{N}$} & \multicolumn{1}{c|}{ Mean } & SD & Df & t-cal. & t-crit. & Verdict \\
\hline Male & 186 & 3.20 & .73 & 320 & .98 & \pm 1.96 & Ho retained \\
\cline { 1 - 4 } Female & 134 & 2.95 & .76 & & & & \\
\hline
\end{tabular}

Level of Significance $=0.05$

Table 4 revealed t-test summary of sex opinion on ways to provider job security for workers. The result proved that sex opinion does not significantly differ on ways missionary education centres provide job security for workers in Delta State missionary education centres with t-cal. value of .98 which is less than $t$-crit. value of \pm 1.96 at 0.05 level of significance.

Hypothesis 2: Administrators experience does not significantly differ on rating of workers productive.

Table 5: t-test summary of administrators' experience opinion on ways to provider job security for workers

\begin{tabular}{|l|l|l|l|l|l|l|l|}
\hline $\begin{array}{l}\text { Administrators } \\
\text { Experience }\end{array}$ & $\mathbf{N}$ & Mean & SD & Df & t-cal. & t-crit. & Verdict \\
\cline { 1 - 4 } Experienced & 71 & 3.14 & .71 & 112 & 1.26 & \pm 1.96 & Ho retained \\
\hline Less Experienced & 41 & 2.88 & .81 & & & \\
\hline
\end{tabular}

Level of Significance $=0.05$

Table 5 revealed t-test summary of administrators' experience opinion on ways to provider job security for workers. The result proved that administrators experience does not significantly differ on rating of workers productive in Delta State missionary education centres with $\mathrm{t}$-cal. value of 1.26 which is less than $t$-crit. value of \pm 1.96 at 0.05 level of significance. 
INTERNATIONAL JOURNAL OF ACADEMIC RESEARCH IN PROGRESSIVE EDUCATION AND

DEVELOPMENT

Vol. 9, No. 4, 2020, E-ISSN: $2226-6348$ @ 2020 HRMARS

Hypothesis 3: Employers and employees mean rating does not significantly differ on how workers job security influence productivity in Delta State missionary education centres.

Table 6: t-test summary of employers and employees mean rating on how workers job security influence productivity

\begin{tabular}{|l|l|l|l|l|l|l|l|}
\hline Category & $\mathbf{N}$ & Mean & SD & Df & t-cal. & t-crit. & Verdict \\
\cline { 1 - 3 } Employers & 114 & 3.12 & .80 & 434 & 1.33 & \pm 1.96 & Ho retained \\
\cline { 1 - 4 } & 322 & 2.73 & .71 & & & & \\
\hline
\end{tabular}

Level of Significance $=0.05$

Table 6 revealed t-test summary of employers and employees mean rating on how workers job security influence productivity. The result proved that employers and employees mean rating does not significantly differ on how workers job security influence productivity in Delta State missionary education centres with $t$-cal. value of 1.33 which is less than t-crit. value of \pm 1.96 at 0.05 level of significance.

\section{Discussion of Results}

Finding shows that ways to provide job security for workers includes; constant training of workers, provide adequate physical and instructional facilities, encourage workers to attend professional development programmes, allow workers to be passive when making decision, make workers feel the impact of management through democratic leadership and seek workers' view on how to enhance the school. Test of hypothesis revealed that sex opinion does not significantly differ on ways missionary education centres provide job security for workers in Delta State missionary education centres. This finding support Javed and Siddiqui, (2012) who revealed that worker job security arises from firm's own policies and practices with the workers which make employees more secure or insecure on the job. Senol, (2011) who stated that worker job security is a core substantial feature of employee's satisfaction which expresses the overall attitude of the worker towards their job.

Finding shows that areas workers are productive includes; task assigned to workers were delivered, teaching students, preparing lesson note, making students scripts, preparing students results, ensure that discipline is maintained within the school and regular to school. Test of hypothesis revealed that administrators experience does not significantly differ on rating of workers productive in Delta State missionary education centres. This finding supports Ugwu and Ugwu (2017) whose findings revealed that librarians job performance was high when compared to task performance. Farhad, Ayyub and Rostam (2014) who reported that that there is significant relationship between organizational climate; organizational commitment; organizational citizenship behaviour and job involvement. Akangbou (2008) who reported that performance is often measured as a ratio of output to input. In the educational arena, performance, therefore, refers to the ratio between the totality of educational output and the resources input that was made use in the production outlay, which to some extent focuses on the cost of production.

Finding shows that influence of job security on workers' productivity includes make workers productive on their task, give workers sense of belonging, help workers to be dedicated to their job, make workers abide to school rules, acquire more skills on the job, reduce workers interest to leave the job and fulfil psychological need of the workers. Test of hypothesis revealed that 
employers and employees mean rating does not significantly differ on how workers job security influence productivity in Delta State missionary education centres. This finding could be as a result that workers who are guaranteed of their job will not be influenced by job mobility. This finding supports Lankford (2002) that job security is intrinsic and extrinsic variables which workers reflect on when deciding on how long they intend to stay on the job. Lankford (2005) maintained that lack of job security is correspondingly responsible for teachers' turnover rate. Candle (2010) study which revealed that employers related factors such as teachers' job security, salary and working condition had a significant effect on teachers' turnover. Aloysius and Ngozika (2019) revealed positive substantial relationship between teachers' job security and retention.

\section{Conclusion}

Conclusively, Delta State missionary education centres can provide job security for workers through constant training of workers, adequate physical and instructional facilities, allow workers to be passive when making decision, make workers feel the impact of management through democratic leadership and seek workers' view on how to enhance the school. Also, workers are productive in several areas such as in teaching students and ensure that discipline is maintained within the school. Thus, job security influence workers' productivity by making them to be productive on their task, give workers sense of belonging, make workers abide to school rules, acquire more skills on the job, reduce workers interest to leave the job and fulfil psychological need of the workers.

\section{Recommendations}

From the findings and conclusion, it is therefore recommended that;

1. There should be constant training of workers as well as provide adequate physical and instructional facilities by missionary schools in Delta State.

2. Workers should be allowed to participate in decision making, through this, workers will feel the impact of the school organisation as feel less insured in the school.

3. Workers should constantly be encouraged to put in their best on the job by assigning task to workers and ensure that discipline is maintained within the school.

4. School administrators in Delta State missionary schools should make appropriate provision for quality conditions of service for teachers. Also during staff induction, teachers should be guaranteed of their job within the school.

\section{References}

Abolade D. A. (2018). Impact of employees' job insecurity and employee turnover on organisational performance in private and public sector organisations. Studies in Business and Economics, 13(2)/2018

Abolade, D. A. (2013): Literacy, an investment in women and human resource development, Lambert Academic Publishing: Deutschland.

Blazer, C. (2006). Literature review on teacher transfer and turnover. Journal of Human Resources, 36(3): 28-35.

Candle, J. (2010). Factors affecting teachers' turnover in private secondary schools in Wakisco District. Unpublished M.Ed. Thesis, Kampala, Uganda: Makerere University. 
INTERNATIONAL JOURNAL OF ACADEMIC RESEARCH IN PROGRESSIVE EDUCATION AND

DEVELOPMENT

Vol. 9, No. 4, 2020, E-ISSN: $2226-6348$ @ 2020 HRMARS

Chaika, G. (2002). The teacher shortage: Apply please. Educational World. Available from http://www.educationalworld.com/admin.admin 155 [Accessed November 06, 2020].

Coulter, M. A., and Abney, P. C. (2009). A study of burnout in international and country of origin teachers. International Review of Education, 55(1): 105-121. Available at: https://doi.org/10.1007/s11159-008-9116-x.

De Witte, H. (2005), Job insecurity: Review of the international literature on definitions, prevalence, antecedents and consequences, SA Journal of Industrial Psychology, vol, 31(4) 1-6.

Kamara, F. (2002). As acute teacher shortage hit countryside: GTU President speaks out. The Daily Observer, pp: 12.

Langbert, M. (2012). The effect of teachers' relationship with management. Management Decision, 40(10): 932-937.

Lankford, H. G. (2002). Teachers sorting and the plight of urban schools: A descriptive analysis. Educational Evaluation and Policy Analysis, 24(1): 37-63. Available at: https://doi.org/10.3102/01623737024001037.

Lankford, H. G. (2005). Explaining the short careers of high achieving teachers in schools with low performing students. American Economic Review, Papers and Proceedings, 95: 166-171.

Mali, P. (2015). Improving Total Productivity. New York: John Wiley Press.

Marr, C. (2015). Assimilation Through Education. University of Washington

Mukumbira, R. (2001). Zimbabwe loses 2000 teachers News24.com. Available from http://www.news24.com/zimbabwe/0. 11113, 2-259_990572,00. html [Accessed November 06, 2020].

Nwachukwu, C. C. (2016). Management Theory and Practice. Onitsha: Africana - Fep. Publishers. Ogunu, M. (2014) 100 Years of Church - State Partnership in Education in Nigeria (1914 - 2014): A Critical Analysis. Benin: Mabogun Publishers.

Olaniyan, A. O. (2009). Principal Preparation, Selection and Leadership Roles" Teachers and Teaching in Nigeria. Festa Press Ltd, Benin. 73-88.

Senem, N., and Ozgur B. (2017). The influence of job insecurity on performance outcomes among employees of Turkish TV serial industry. Bilgi Ekonomisi ve Yönetimi Dergisi / 2017 Cilt: XII Sayı: II

Subramaniam, C., Shamsudian, F. M., and Ibrahim, H. (2011), Linking human resource practices and organisational performance: Evidence from small and medium organisations in Malaysia, Journal of Pengurusan, vol. 32, pp. 27-37.

Werang, B. R. (2014). Principals' Administrative Skills, School Organizational Climate, and Staff' Work Morale at State Senior High Schools in Merauke Regency-Papua-Indonesia. International Journal of Science and Research (IJSR), 3(6), 691-695.

Farhad, G., Ayyub, S., and Rostam, D. (2014). Explaining the Relationship between Organizational Climate, Organizational Commitment, Job Involvement and Organizational Citizenship Behavior among Employees of Khuzestan Gas Company. Mediterranean Journal of Social Sciences, 5(20), 2986-2996

Akangbou, S. D. (2008) Productivity Trends in Secondary Grammar School Education in Bendel State of Nigeria (1974-1985). The Nigerian Journal of Economics and Social Studies 20(3), 451-452. 